1951. Pp. 12. British Standards Institution, London). After all, many scientific and technological books are, in fact, a series of related papers, treating logically of various phases of a specific subject; as such, they merit a proper and comprehensive index, not only for the student of the subject, but even more for others, perhaps in different disciplines, who have to refer quickly to relevant author or subject details. At the other extreme, there is the type of index which is self-defeating because it emphasizes the wrong word, for example, the adjective, not the noun.

A case in point is emphasized by the writer of a notice of a recent British official technical publication, Research on Road Traffic (Pp. 517. London: H.M.S.O. 42s.) in the Road Research Unit Newsletter No. 9 (October 1965. National Roads Board, New Zealand: Wellington, P.O. Box 8024). After paying tribute to this volume, he says: "It is easy to criticize the layout of indexes; yet many criticisms deserve attention. The main charge is against 'hybridization' which supplants the essentials', He comments on ". . . the format technicalities ... obsessed with system rather than with simple usage" and goes on to say: "Nothing produces such exasperation in a reader as a hunt for relevant figures, diagrams, tables, plates . . . which are each given separate numerical sequences; and therefore 'it's every man for himself'". Instances are quoted: 'Safety Kerbs' are not shown under ' $K$ ' or ' $S$ '; they appear under ' $C$ ' and ' $R$ '; 'Barriers' do not appear under ' $B$ ', but under ' $R$ ' they get two mentions; the list is extended. This writer also makes the foregoing point that indexes so often fail because the author insists on giving preference to an adjective rather than to the basic noun. In many text-books the ideal in indexing is achieved where author and subject indexes are separated; where the subject index really does list the essential nouns in each chapter, whether preceded by capital letter or in lower case, followed by as many qualifying adjectives as may be appropriate. But what is here called 'typographic pedantry' is surely to be avoided at all costs. An example of a clear, concise, rapidly informative subject index is the Index to N.B.R.I. Information Sheets recently received (National Building Research Institute, South African Council for Scientific and Industrial Research. CSIR Technical Note $X / B O U 100$; Building Series Dis. 100. Pp. 10. Pretoria, May 1965). But a model for authors is undoubtedly the Subject Index to List of British Standards, included in each annual volume of the British Standards Yearbook; for the art of indexing and particularly of cross-referencing, this takes a lot of beating.

\section{Check-list of British Lichens}

A NEw check-list of British lichens was published by the British Lichen Society in the 1965 number of The Lichenologist. It was prepared by P. W. James, of the British Museum (Natural History). The list is notable for aligning the names of the 1,347 British species with those used elsewhere in the world, while ensuring that the nomenclature conforms to the International Code of Botanical Nomenclature. Interleaved copies of the checklist are obtainable from the treasurer of the British Lichen Society, Dr. T. D. V. Swinscow, 103 London Road, Knebworth, Hertfordshire, price $7 s .6 d$, post free.

\section{Lady Tata Memorial Trust International Grants, Scholar- ships and Fellowships for Research on Leukaemia and Allied Conditions}

THE Trustees of the Lady Tata Memorial Trust invite applications for fellowships, scholarships and grants for research on leukaemia, in the academic year beginning October 1, 1966. In view of the affinity between leukaemia and other forms of neoplastic disease, candidates with programmes of research on any aspect of malignant disease which may throw light on problems of leukaemia will be eligible for consideration. The Trustees specially wish to encourage investigations of the leukaemogenic viruses in mammals, the epidemiology and natural history of leukaemia, and the immunogenic aspects. The awards offered by the Trust are open to suitably qualified investigators of any nationality, working either in their own institutions or in other centres abroad. Further information and forms of application can be obtained from the Secretary of the (European) Scientific Advisory Committee, Lady Tata Memorial Trust, Chester Beatty Research Institute, Fulham Road, London, S.W.3. Applications must be submitted before March 31, 1966.

\section{Fulbright Travel Grants}

UNDER the provisions of the Fulbright programme, travel grants are available to citizens of the United Kingdom and dependent territories to go to the United States of America for academic or educational purposes, provided that they have adequate financial support in dollars for the proposed period of the visit to the United States. Those applicants who are graduate students must show proof of the admission to an institution of higher learning in the United States for a minimum period of nine months, whereas those who are professors, lecturers and senior research scholars must hold an appointment to undertake lecturing or advanced research at an approved American institution of higher learning. All grants cover the cost of direct round-trip travel between a candidate's home and the American university or institution. For graduate students the departure dates are between June 1, 1966, and July 31, 1966, for which applications must be received before April 1, 1966; and between August 1, 1966, and April 1, 1967, for which applications must be received before May 15, 1966 . For professors, lecturers and senior research scholars the departure dates are between June 1, 1966, and July 31, 1966, for which applications must be received before March 16, 1966; and between August 1, 1966, and April 1, 1967, for which applications must be received by June 1, 1966. Application forms and further information can be obtained from the United States-United Kingdom Educational Commission, 71 South Audley Street, London, W.1.

\section{Endeavour Prizes}

Prizes totalling more than $£ 200$ are offered by Imperial Chemical Industries, Ltd., publishers of the international scientific review, Endeavour, for essays submitted on scientific subjects. In addition to the cash prizes, the prizewinners will receive invitations to attend the whole of the British Association meeting at Nottingham during August 31--September 7. Accommodation will be provided in Nottingham and travelling expenses within the United Kingdom will be paid. As the primary purpose of these awards is to stimulate younger scientists to take an interest in the work of the British Association and to raise the literary standard of scientific writing, the competition is restricted to those whose twenty-fifth birthday falls on or after September 1, 1966. Five prizes will be awarded, namely: a first prize of 100 guineas; a second prize of 50 guineas; a third prize of 25 guineas; and two special prizes of 10 guineas each for competitors who have not passed their eighteenth birthday on September 1, 1966. The subjects for the essays are as follows: (1) mechanisms of morphogenesis; (2) the pattern of subnuclear particles; (3) microcircuitry; (4) chemicals in agriculture; (5) the cell surface; (6) recent advances in thermochemistry. The essays, which must be in English and typewritten, should not exceed 4,000 words in length, and only one entry is permitted from each competitor. All entries should be addressed to : the Deputy Secretary, British Association for the Advancement of Science, 3 Sanctuary Buildings, Great Smith Street, London, S.W.1, and the envelope should be clearly marked 'Endeavour Prize Essay'. The latest date for receipt of entries is June 1, 1966. The essays must be submitted without signature, and the competitor's full name and 